\title{
Structural changes of protein antigens due to adsorption onto and release from aluminium hydroxide using FTIR-ATR
}

\author{
Yiwu Zheng a,b, Xuxin Lai ${ }^{\text {a,b }}$, Henrik Ipsen ${ }^{\text {a }}$, Jørgen Nedergaard Larsen ${ }^{\text {a }}$, \\ Henning Løwenstein ${ }^{\mathrm{a}}$, Ib Søndergaard ${ }^{\mathrm{b}}$ and Susanne Jacobsen ${ }^{\mathrm{b}, *}$ \\ ${ }^{\text {a } A L K-A B E L L O ~ A / S, ~ H \phi r s h o l m, ~ D e n m a r k ~}$ \\ ${ }^{\mathrm{b}}$ Enzyme and Protein Chemistry, BioCentrum-DTU, Technical University of Denmark, \\ Kgs. Lyngby, Denmark
}

\begin{abstract}
Structural integrity of antigens upon adsorption and release is not only important for investigating vaccine immunogenicity, but also for the epitope specificity of the resulting immune response and hence therapeutic efficacy. Moreover, the structural information is also important for understanding the mechanism of how adjuvants can enhance the immune response. However, little is known about an antigen's structure when it is adsorbed on and subsequently released from aluminium adjuvants. In this study, the structures of two protein antigens, bovine serum albumin and $\beta$-lactoglobulin, were investigated using Fourier transform infrared-attenuated total reflection (FTIR-ATR) spectroscopy. The secondary structures of both model antigens change when adsorbed to aluminium hydroxide. The structural perturbation depends on the amount of adsorbed protein. Maximal adsorption gives a more native-like structure. This may indicate that protein is adsorbed in different manners depending on the concentration. The adsorbed antigens are released using phosphate buffer $\mathrm{pH} 7.4(\mathrm{~PB})$. The recovery is approximate $80 \%$ after $40 \mathrm{~min}$ in the presence of PB. The recovery curves of both proteins also indicate two different adsorption modes. FTIR-ATR and circular dichroism (CD) spectroscopy yield similar results suggesting that the adsorbed antigens refold to their native-like state after release.
\end{abstract}

Keywords: Antigen, secondary structure, FTIR-ATR, aluminium hydroxide

\author{
Abbreviations \\ BSA Bovine serum albumin; \\ BLG $\beta$-Lactoglobulin; \\ FTIR Fourier transform infrared spectroscopy; \\ ATR Attenuated total reflection; \\ PB Phosphate buffer solution; \\ CD Circular dichroism; \\ BLA Bovine $\alpha$-lactalbumin.
}

\footnotetext{
*Corresponding author: Susanne Jacobsen, Enzyme and Protein Chemistry, BioCentrum-DTU, Technical University of Denmark, Søltofts Plads, Building 224, 2800 Kgs. Lyngby, Denmark. Tel.: +45 4525 2741; Fax: +45 4588 6307; E-mail: sja@biocentrum.dtu.dk
} 


\section{Introduction}

Antigens are proteins capable of inducing specific immune responses when injected to humans. The molecular properties of antigens and the way in which these properties contribute to immune activation are central to determine the outcome of vaccination. All four levels of protein organization - primary, secondary, tertiary, and quaternary - affect its immunogenicity [1]. The structural information of the antigen is not only important for investigating its immunogenicity; it is also important in the understanding of interactions between antigen and adjuvant and the mechanism of how adjuvant can enhance the immune response. In general, proteins have a very fragile three-dimensional structure [2,3], and this structure may easily change in different environments, such as binding to membranes, at air-water interfaces, under pressure, or even during drying and storage. Protein adsorption processes are believed to cause structural changes in the protein. Previous studies [4-8] have shown that adsorption of a protein onto interfaces or solid surfaces induce structural changes in the protein. The structural change during absorption may lead to irreversible aggregate formation, prevent the ability to induce an immune response, or even cause serious side-reactions. Protein aggregation is difficult to control and hampers precise prediction of the release profile of the protein. Furthermore, protein aggregates may potentially constitute risk to patients.

Aluminium adsorbed vaccines have been safely used for many years. However, the structure of the antigen, when adsorbed to aluminium-containing adjuvants, has not been well characterized. Only a few studies [9-11] have addressed the structure of aluminium adsorbed proteins due to the lack of experimental techniques allowing structural information to be obtained directly on this complex system. Hem and White [9] demonstrated that a slight deformation of the structure of pepsin occurred when adsorbed by aluminium hydroxide using infrared spectroscopy. They regarded this as an example of ligand exchange. Jones et al. [10] studied the structural changes of model antigens as a function of temperature by FTIRATR spectroscopy to investigate vaccine stability. However, Dong and his co-workers [11] showed that protein antigen did not change its secondary structure due to adsorption onto aluminium adjuvants by FTIR-ATR. To our knowledge, there is no available structural information of released antigens from aluminium-containing adjuvants.

FTIR spectroscopy is a method well suited to determine the secondary structure of globular proteins. It offers many advantages over other spectroscopic techniques [12,13]. A major advantage is the lack of dependence on the physical state of the sample. The sample can either be gas, aqueous or organic solution, hydrated film, inhomogeneous suspension, or solid. FTIR is particularly suitable for the analysis of proteins adsorbed by other materials, especially when an ATR crystal is used. FTIR was applied to study the loss of secondary structure during insulin unfolding in a lipid-water interface model [14] and protein adsorption by silica, polysulfone, and other biomaterials [15-18]. The assignments of secondary structure bands of protein in a FTIR spectrum are shown in [19-24].

CD spectroscopy is a method suited to monitor the secondary and tertiary structure of proteins in solution [25]. Far-UV CD (170-250 nm) spectroscopy is a good tool to obtain the overall information of the secondary structure. However, the analyses involve complex calculations using a standard set of reference proteins as a basis for estimation and thus yield only indirect measures [26]. Moreover, CD spectroscopy is not a suitable technique for measuring the adsorbed protein in suspension because light cannot pass through such high density samples.

In this study, FTIR-ATR and CD spectroscopy were applied to investigate the structural changes of protein antigens. Model antigens were adsorbed by aluminium hydroxide and subsequently released using phosphate buffer (PB) at $\mathrm{pH}$ 7.4. $\mathrm{PB}$ was chosen because phosphate anions easily adsorb onto the 
surface of aluminium hydroxide through ligand exchange displacing the antigens from the aluminium adjuvant [27]. Bovine serum albumin (BSA) and $\beta$-lactoglobulin (BLG) were used as model antigens because their structures have been well studied. They are $\alpha$-helix-rich and $\beta$-sheet-rich proteins, respectively. BSA consists of $66 \% \alpha$-helix and BLG contains $46 \% \beta$-sheet [28]. BSA is a small globular protein with a molecular weight of approximate $66.4 \mathrm{kDa}$, and pI of BSA is 4.8 [29]. BLG has a well-known structure containing one very short helix segment and eight strands of anti-parallel $\beta$-sheet, which wrap to form an anti-parallel $\beta$-barrel. BLG exists at neutral $\mathrm{pH}$ as a dimer in its native state. Each monomer is identical and constitutes of 162 amino acids, with one free thiol group and two disulphide bridges. The $\mathrm{pI}$ of BLG is 6.5 and the molecular weight is approximately $18 \mathrm{kDa}[30,31]$.

\section{Materials and methods}

\subsection{Materials}

Clinical reagent grade BSA (reference L84960) and approximate 90\% pure BLG (reference L3908) were purchased from ICN biomedical Inc and Sigma respectively. Both proteins were used directly without further purification. Aluminium hydroxide adjuvant was purchased from Superfos Biosector $\mathrm{A} / \mathrm{S}$ (Denmark) and used without further treatment. Other chemicals were all of analytical grade and obtained from commercial sources.

\subsection{Adsorption experiments}

\subsubsection{Sample preparation}

A protein stock solution $(10 \mathrm{mg} / \mathrm{ml})$ was prepared by dissolving protein in Milli-Q water. Working samples were prepared by mixing the appropriate amount of protein stock solution and aluminium hydroxide and subsequently diluting to $1 \mathrm{ml}$ using Milli-Q water. The final calculated aluminium concentration was $3.4 \mathrm{mg} / \mathrm{ml}$ for all samples; the final protein concentrations were from $1 \mathrm{mg} / \mathrm{ml}$ to $5 \mathrm{mg} / \mathrm{ml}$. Samples were mixed gently for 30 min to obtain the maximum protein adsorption before FTIR-ATR measurement.

\subsubsection{FTIR-ATR measurement}

Spectra were collected using a FTIR spectrometer (PerkinElmer Spectrum One), which was mounted with a three bounces ZnSe ATR crystal (PerkinElmer). An $8 \mu$ sample was deposited onto the ATR crystal by evaporating the solvent to obtain a film. The calculated amount of aluminium hydroxide for a film was $27.2 \mu \mathrm{g}$; and the calculated value of protein was from $8 \mu \mathrm{g}$ to $40 \mu \mathrm{g}$, respectively. Spectra were directly recorded on the film by co-adding 128 scans with a resolution of $4 \mathrm{~cm}^{-1}$ at a scan speed $0.2 \mathrm{~cm} / \mathrm{s}$. Control spectra were collected from samples containing the same components except protein and at same experimental conditions. All samples were analyzed at least in duplicate.

\subsection{Release experiments}

\subsubsection{Sample preparation}

Adsorbed protein antigens were prepared as described in Section 2.2. The final concentration of aluminium hydroxide was $3.4 \mathrm{mg} / \mathrm{ml}$ for each sample; final protein concentration was $4 \mathrm{mg} / \mathrm{ml}$ for BSA and $3 \mathrm{mg} / \mathrm{ml}$ for BLG. The samples were gently rotated at room temperature for one hour, and stored at $4^{\circ} \mathrm{C}$ overnight. Adsorbed proteins were released by adding PB pH 7.4 to a final concentration from 5 to $200 \mathrm{mM}$ at room temperature. Samples were incubated for $40 \mathrm{~min}$ before FTIR-ATR analysis. 


\subsubsection{FTIR-ATR measurements}

FTIR-ATR measurements were performed on the same instrument as described in Section 2.2. Measuring films were made in either of two ways: by evaporating the complex of protein and aluminium hydroxide; or by measuring released protein alone after centrifugation at $6800 \times \mathrm{g}$ for $10 \mathrm{~min}$. Blank samples containing the same components except protein were analyzed under the same condition. All samples were measured at least in duplicate.

\subsubsection{CD measurements}

Adsorbed protein was released using PB pH 7.4 at a final concentration of $150 \mathrm{mM}$ for $40 \mathrm{~min}$. Control samples were prepared using the same components except protein. Free protein solutions were prepared by dissolving appropriate amounts of protein in the supernatant which was obtained from control experiment.

CD measurements were carried out using an Olis spectropolarimeter (On-line instrument systems, Inc., USA), equipped with a temperature control system. Protein solutions were scanned in a $0.1 \mathrm{~cm}$ quartz cuvette five times at $15^{\circ} \mathrm{C}$. In order to compare the $\mathrm{CD}$ spectra of the free protein and the released protein, protein concentrations were identical. Free protein solutions were also measured from $15^{\circ} \mathrm{C}$ to $90^{\circ} \mathrm{C}$, with $5^{\circ} \mathrm{C}$ interval. At each temperature, the sample was incubated for $2 \mathrm{~min}$ before scanning.

\subsubsection{Ultraviolet (UV) spectrophotometric measurements}

After 40 minutes release, the samples were centrifuged at $6800 \times \mathrm{g}$ for $10 \mathrm{~min}$, and the supernatants were measured using an UV/VIS spectrophotometer (Lamda 800, PerkinElmer instruments) at 280 and $320 \mathrm{~nm}$. The protein recovery from aluminium hydroxide was calculated from the following equation:

$$
R=\frac{\left(A_{280}^{\prime}-A_{320}^{\prime}\right) / \varepsilon-\left(A_{280}-A_{320}\right) / \varepsilon}{A C} \times 100 \%,
$$

where $R$ is protein recovery, $\varepsilon$ is extinction coefficient, $A C$ is adsorption capacity, $A_{280}$ is the absorbance of protein at $280 \mathrm{~nm}$ in Milli-Q water. $A_{280}^{\prime}$ is absorbance at $280 \mathrm{~nm}$ in the presence of PB, likewise with $A_{320}$ and $A_{320}^{\prime}$.

\subsection{Data analysis}

\subsubsection{FTIR data}

All FTIR spectra were analyzed using Unscrambler Ver. 9.2 software (Camo process AS). The replicated spectra of the same sample were averaged first. The spectrum of a corresponding blank sample was subtracted from the spectrum of adsorbed proteins. A flat baseline from 1900 to $1740 \mathrm{~cm}^{-1}$ was obtained for each spectrum after background subtraction. A window size of 23-point Savitsky-Golay smoothing function was applied to each spectrum. The second derivative spectra were calculated using a window size of 11-point Savitsky-Golay function from 1750 to $1220 \mathrm{~cm}^{-1}$. The inverted second derivative spectra were obtained by multiplying with -1 for convenient interpretation. Finally, the spectra were baseline corrected, mean normalized, transferred into Excel file and plotted.

\subsubsection{CD data}

Before analysis, a CD spectrum of a control sample, which contained all components except protein, was subtracted from each $\mathrm{CD}$ spectrum. 


\section{Results and discussion}

\subsection{Protein adsorption by aluminium hydroxide}

Typical FTIR spectra of BSA and BLG adsorbed by aluminium hydroxide and recorded on films are shown in Fig. 1(A). For comparison, the spectrum of pure aluminium hydroxide is also presented in same figure. It is seen that amide I $\left(1700-1600 \mathrm{~cm}^{-1}\right)$ and amide II $\left(1600-1500 \mathrm{~cm}^{-1}\right)$ bands are not affected by the absorption of aluminium hydroxide enabling the aluminium hydroxide background subtraction. The subtracted spectra in the region from $1900 \mathrm{~cm}^{-1}$ to $1200 \mathrm{~cm}^{-1}$ are given in Fig. 1(B). Subtraction of background is dangerous, because over or under subtraction of the spectra may damage the final spectra. A simple and practical method is to subtract background until the region from 1900 to $1740 \mathrm{~cm}^{-1}$ is flat. This method works well with most proteins when adsorbed by other materials, if it is applied consistently. However, studies have also shown that the positions and intensities of the bands are maintained even with deliberate over or under subtraction of the background spectrum [32]. In this study, potential alterations of the secondary structure of model antigens are monitored in the amide I and amide II region of the final inverted 2nd derivative FTIR spectra.

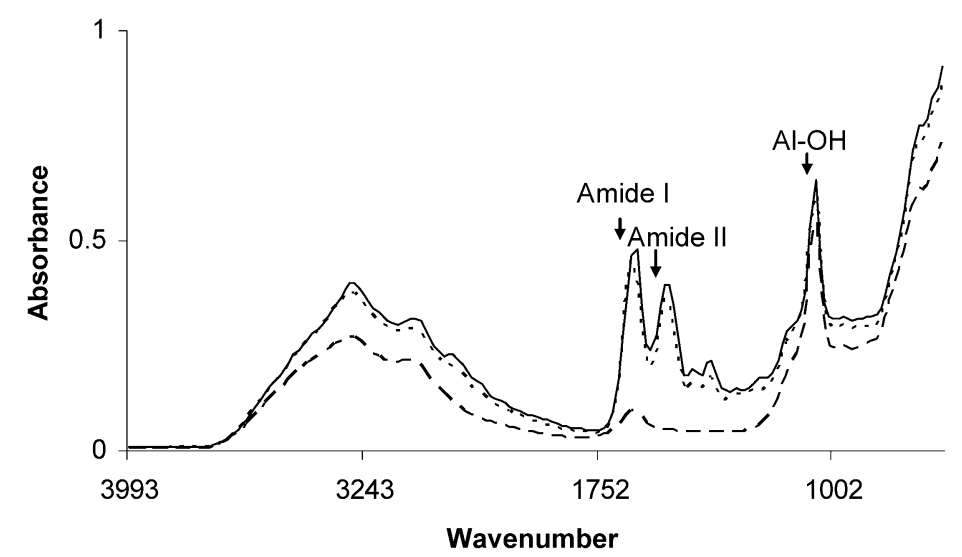

(A)

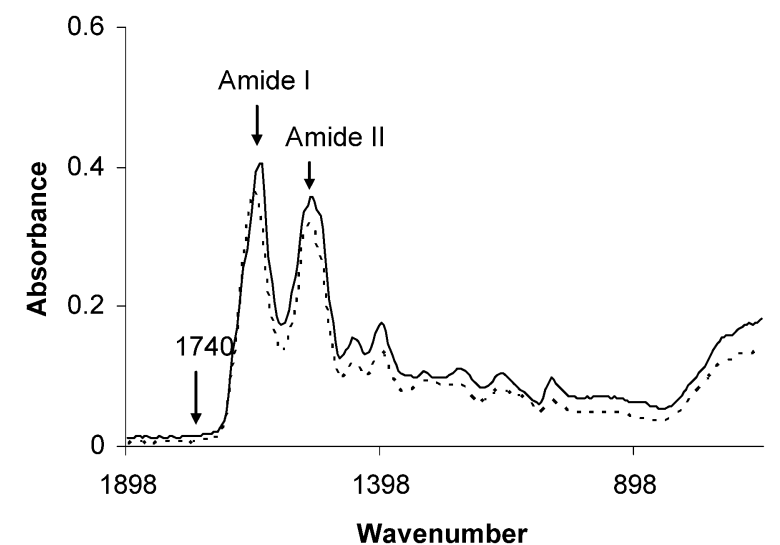

(B)

Fig. 1. Typical FTIR spectra of protein before (A) and after (B) subtraction of aluminium hydroxide: absorbed BSA (dotted line), adsorbed BLG (solid line), and aluminium hydroxide (dashed line) (A); BSA (dotted line) and BLG (solid line) (B). 


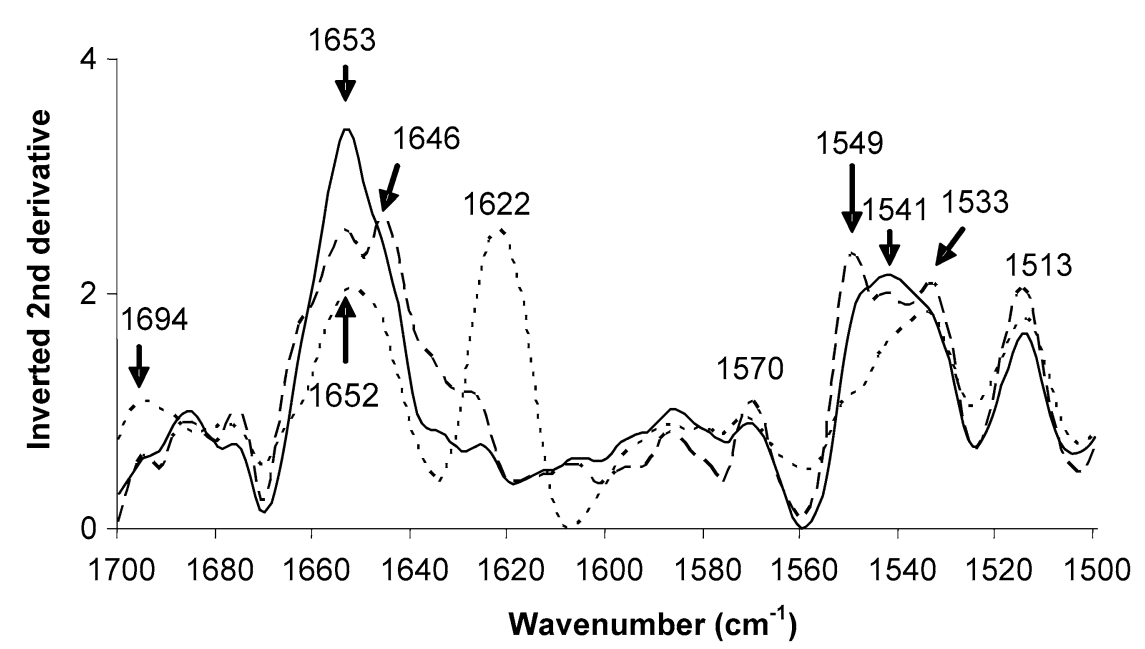

Fig. 2. Inverted 2nd derivative spectra of BSA in amide I and amide II region: free BSA (solid line), adsorbed BSA (dashed line) and aggregated BSA (dotted line).

The inverted 2nd derivative FTIR spectra of free BSA, adsorbed BSA and aggregated BSA are given in Fig. 2. Except when specifically mentioned, in this paper free protein means pure protein in solution; adsorbed protein means protein adsorbed onto aluminium hydroxide; and the aggregated protein is protein that has been preheated at $90^{\circ} \mathrm{C}$ for $30 \mathrm{~min}$. In Fig. 2 there are band-broadening and the introduction of new peak for adsorbed BSA in amide I and amide II regions. A new peak at $1646 \mathrm{~cm}^{-1}$ is introduced and can be assigned to random structure. A band at $1653 \mathrm{~cm}^{-1}$ decreases in intensity, which ascribes to $\alpha$-helix. In other words, adsorbed BSA loses its $\alpha$-helix but gains random structure in amide I range. In amide II region, two new bands are induced at $1549 \mathrm{~cm}^{-1}$ and $1533 \mathrm{~cm}^{-1}$. The band around $1570 \mathrm{~cm}^{-1}$ and $1513 \mathrm{~cm}^{-1}$ increases in intensity due to adsorption, respectively. The significant difference in the spectra of adsorbed BSA and free BSA indicates that the secondary structure of BSA changes when adsorbed onto aluminium hydroxide.

In order to compare the structural difference of adsorbed protein and the aggregated denatured protein, BSA was preheated at $90^{\circ} \mathrm{C}$ for $30 \mathrm{~min}$ and the spectrum was recorded under identical experimental condition. The final inverted 2nd derivative spectrum of aggregated BSA is also shown in Fig. 2. For aggregated BSA, there are two new bands around $1622 \mathrm{~cm}^{-1}$ and $1694 \mathrm{~cm}^{-1}$ in the amide I region. The band at $1622 \mathrm{~cm}^{-1}$ is extremely strong. These two bands relate to intermolecular anti-parallel $\beta$-sheet formation. The result agrees with other heat-denatured protein aggregates [33-35]. In the amide II range, aggregated BSA loses intensities at $1549 \mathrm{~cm}^{-1}$ and $1541 \mathrm{~cm}^{-1}$ compared to adsorbed and free BSA. These significant differences indicate that the adsorption-induced secondary structural change is not the same as observed for protein aggregation.

We have also studied protein adsorption capacity by aluminium-containing adjuvants. Aluminium hydroxide can adsorb different amounts of protein depending on the protein. Adsorption of different amounts of protein may not result in same structural changes. To elucidate the absorption level effect, we investigated the structures at different protein to aluminium hydroxide ratios.

Five amounts of BSA, from $8 \mu \mathrm{g}$ to $40 \mu \mathrm{g}$ with $8 \mu \mathrm{g}$ interval, were adsorbed by same amount of aluminium hydroxide $(27.2 \mu \mathrm{g})$, and measured under identical experimental condition. The inverted 2nd derivative spectra are given in Fig. 3. The spectra were significantly different in the amide I and amide II regions due to the intensity changes and peak shifts. For low ratio of adsorbed BSA, e.g. $8 \mu \mathrm{g}$, bands in 


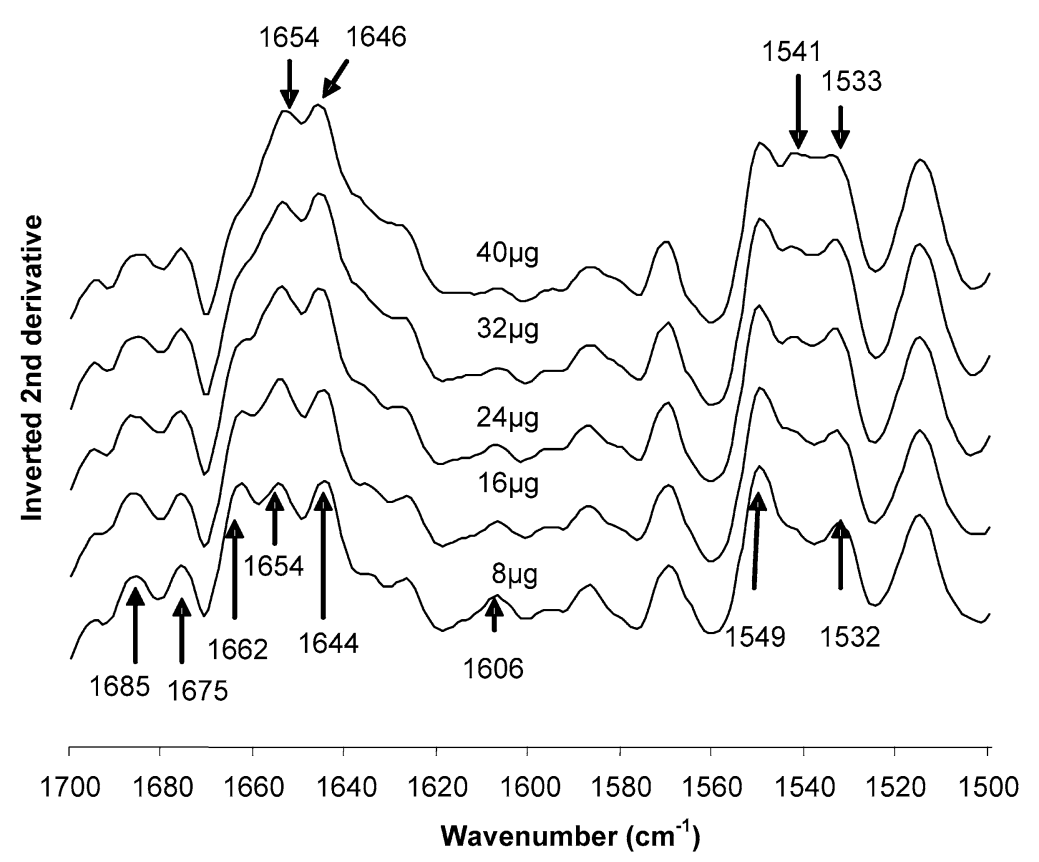

Fig. 3. Inverted 2nd derivative spectra of different amount of BSA adsorbed by same amount of aluminium hydroxide in amide I and amide II region. The spectra have been shifted vertically for case of interpretation.

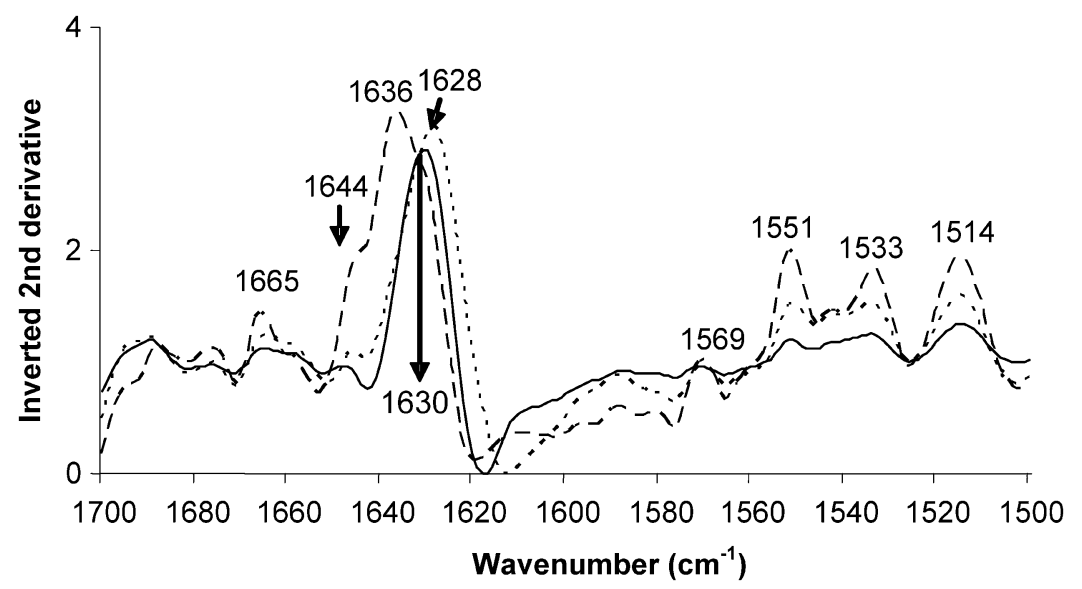

Fig. 4. Inverted 2nd derivative spectra of BLG in amide I and amide II region: free BLG (solid line), adsorbed BLG (dashed line) and aggregated BLG (dotted line).

amide I region increase in intensity around 1685,1675 and $1662 \mathrm{~cm}^{-1}$. On the other hand, in the spectra at a high ratio of adsorbed BSA, e.g. $40 \mu \mathrm{g}$, bands increase around 1654 and $1646 \mathrm{~cm}^{-1}$, which are the $\alpha$-helix and random structure. In the amide II region, at a high ratio of adsorbed protein there is a loss in intensities at 1549 and $1532 \mathrm{~cm}^{-1}$, but the band at $1541 \mathrm{~cm}^{-1}$ increase. The band at $1532 \mathrm{~cm}^{-1}$ shifts to $1533 \mathrm{~cm}^{-1}$ at a low ratio of adsorbed BSA. Therefore, the structure of adsorbed protein depends on how much protein is adsorbed by the aluminium adjuvant. A high ratio of adsorbed BSA gives a native-like structure.

In the case of BLG, the experiments were performed using the same experimental conditions as for BSA. Figure 4 presents the inverted 2nd derivative spectra of free BLG, adsorbed BLG and aggregated 
BLG. The spectral difference between adsorbed BLG and free BLG are due to peak shifts and band broadening in the amide I region, and intensity changes in the amide II region. The broadest band widens and shifts from 1630 to $1636 \mathrm{~cm}^{-1}$ for adsorbed BLG, which can be ascribed to $\beta$-sheet. A shoulder peak is introduced at $1644 \mathrm{~cm}^{-1}$, which can be assigned to random structure. Another difference in the amide I range is the intensity of the band at $1665 \mathrm{~cm}^{-1}$; adsorbed BLG has a stronger absorption. In the amide II region, the intensities of three peaks increase considerably around 1551, 1533 and $1514 \mathrm{~cm}^{-1}$ for adsorbed BLG. These significant spectral alterations indicated that the secondary structure of BLG is dramatically modified when adsorbed by aluminium hydroxide, revealing a strong effect of the aluminium adjuvant on BLG. The result is in excellent agreement with another study, in which BLG rearranged when adsorbed to dimyristoylphosphatidylglycerol (DMPG) [36].

In order to compare the adsorption-modified structure and the heat-induced structure, heat-induced aggregation of BLG was also investigated. Figure 4 presents the spectrum of aggregated BLG. It has been preheated at $90^{\circ} \mathrm{C}$ for $30 \mathrm{~min}$ and measured under identical experimental conditions. The spectrum of aggregated BLG differs from free BLG by band-broadening and band shift from 1630 to $1628 \mathrm{~cm}^{-1}$ in amide I region. In contrast, this band of adsorbed BLG shifts to higher wavenumber, $1636 \mathrm{~cm}^{-1}$. In the amide II range, the intensities of three bands around 1551, 1533 and $1514 \mathrm{~cm}^{-1}$ increase for both aggregated BLG and adsorbed BLG. Surprisingly, adsorbed BLG has stronger absorption for these three bands than aggregated BLG. This is an indication that BLG is not extensively unfolded at this heat process or that the unfolded structure refold when retuning to room temperature. However, the structure is dramatically modified by adsorption onto aluminium hydroxide.

Five concentrations of BLG, from 8 to $40 \mu \mathrm{g}$ with an $8 \mu \mathrm{g}$ interval, were adsorbed by $27.2 \mu \mathrm{g}$ aluminium hydroxide, respectively. FTIR spectra were collected at identical conditions. The inverted 2nd derivative spectra are shown in Fig. 5. Spectral differences are mainly due to band shifts and intensity

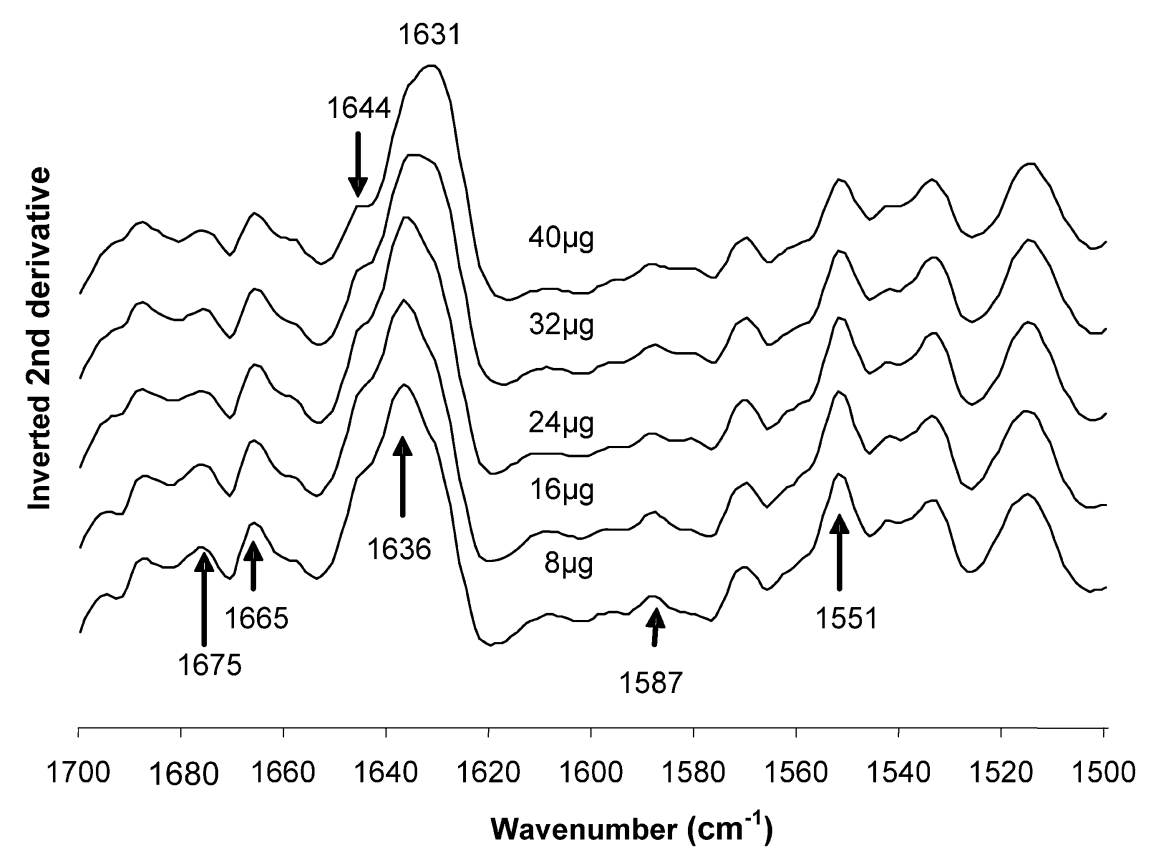

Fig. 5. Inverted 2nd derivative spectra of different amount of BLG adsorbed by same amount of aluminium hydroxide in amide I and amide II region. The spectra have been shifted vertically for case of interpretation. 
changes. The $\beta$-sheet band shifted from $1636 \mathrm{~cm}^{-1}$ to $1631 \mathrm{~cm}^{-1}$ according to increasing protein adsorption, e.g. from $8 \mu \mathrm{g}$ to $40 \mu \mathrm{g}$. The band at $1644 \mathrm{~cm}^{-1}$, which is random structure, loses intensity at a high ratio of adsorbed BLG, e.g. $40 \mu \mathrm{g}$. This phenomenon is different from was observed with adsorbed BSA.

Two bands at 1675 and $1665 \mathrm{~cm}^{-1}$ have stronger absorption at a low ratio adsorbed of BLG. In the amide II range, a low ratio of adsorbed BLG has a stronger absorption at $1551 \mathrm{~cm}^{-1}$. Therefore, the structures differ as a function of amount of adsorbed BLG. The more BLG adsorbed, the more nativelike the structure is. Interference from free BLG in the adsorbed sample cannot be excluded in this case, as BLG can not be totally adsorbed by aluminium hydroxide even at very low concentrations. Free protein may affect the final spectra, especially for high amount of protein adsorption such as $40 \mu \mathrm{g}$.

Protein antigen adsorption is believed to result from electrostatic attraction between protein and aluminium adjuvant. When antigen is adsorbed onto the aluminium surface, the resulting intermolecular electrostatic interaction may weaken the intramolecular forces that stabilize the protein native structure. It may be the reason of adsorption-induced structural changes in the antigens.

The adsorption manner depends on the amount of adsorbed protein, which is in agreement with other studies [37,38]. Urano et al. [37] demonstrated that BSA was adsorbed on the $\mathrm{Al}_{2} \mathrm{O}_{3}$ surface by formation of a monomolecular layer. A model of BSA adsorption was proposed according to which protein was adsorbed in two different configurations depending on the amount of adsorbed protein. Nevertheless, Urano et al. [37] using potentiometric titration could not conclude that protein structure changed due to adsorption. It is probably because the conformation of adsorbed protein depends on the properties of the aluminium hydroxide surface $[39,40]$. In this study, two model proteins are adsorbed by aluminium hydroxide resulting in different conformations. Small amounts of protein are strongly adsorbed by aluminium hydroxide. The protein molecules form a monomolecular layer on aluminium hydroxide and secondary structure becomes more denatured. On the other hand, the structural perturbation of the protein becomes smaller when the degree of banding decreases. A high ratio of adsorbed protein is weakly adsorbed via few linking points. The protein molecules are oriented "perpendicular" onto the aluminium hydroxide, which results in a native-like structure. However, structural changes of the proteins when adsorbed on the ATR crystal cannot be excluded. Previous study showed that the changes in protein structure may occur upon adsorption onto the ATR surface [41].

The mechanism of how aluminium adjuvants can enhance the immune response is still poorly understood. Jones et al. [10] proposed that protein structure became destabilized upon adsorption by aluminium adjuvants. These physical changes of adsorbed antigens made them more susceptible to proteolytic processing by the immune system, resulting in an enhanced antigen presentation. According to this hypothesis, vaccines with low ratio of protein adsorption should induce stronger or similar immune response as compared to high ratio adsorption, since it has a more destabilized structure. The denatured protein may be pharmaceutically inactive for treating purposes, and denaturation may be the reason why causing immunogenicity, which was regarded as side effect in other fields $[42,43]$.

\subsection{Release of protein from aluminium hydroxide}

PB is capable of replacing pre-adsorbed BSA and BLG from aluminium hydroxide. The protein recovery (amount of released proteins/adsorbed protein) at different PB concentration is shown Fig. 6. Protein release from aluminium hydroxide is quite fast; recovery is approximately $80 \%$ within $40 \mathrm{~min}$ both for BSA and BLG. These high values indicate that PB at pH 7.4 is a good candidate for replacement of protein from aluminium hydroxide. Some surfactants have also been used for protein release 


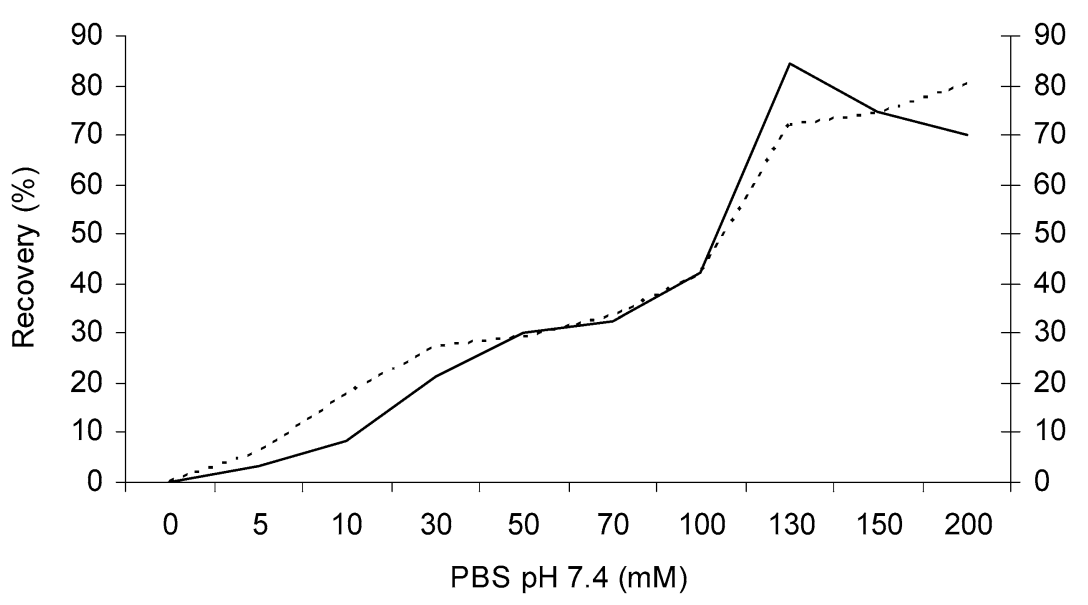

Fig. 6. Recovery of proteins that are first adsorbed by aluminium hydroxide and subsequently released using $\mathrm{pH} 7.4 \mathrm{~PB}$ at different concentrations: BSA (solid line), BLG (dotted line). The incubation time in the presence of PB is 40 min. The recovery was calculated by the released amount/adsorbed protein.

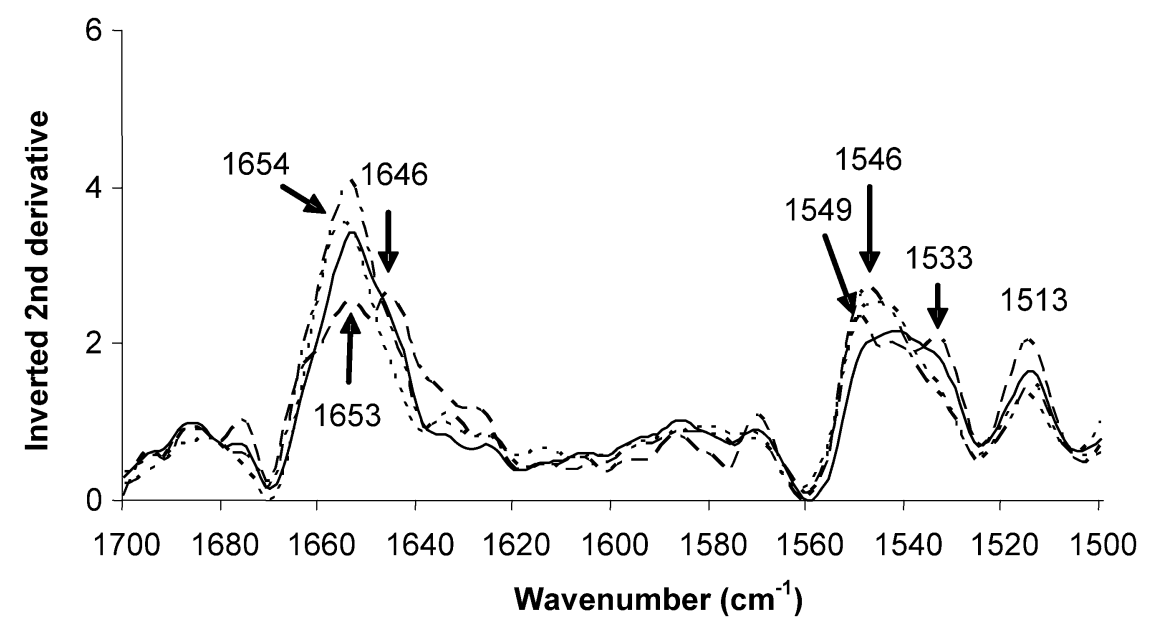

Fig. 7. Inverted 2nd derivative spectra of BSA in amide I and amide II region: free BSA (solid line), adsorbed BSA (dashed line), released BSA, the complex of protein and aluminium hydroxide (dotted line), and released BSA, protein alone after centrifugation (dash-dotted line).

from aluminium adjuvant $[44,45]$. The recovery of protein is proportional to the concentration of buffer, especially for BLG. Both for BSA and BLG, adsorbed protein can not be totally released from aluminium hydroxide. Incomplete release may associate with aggregation. The aggregated protein may not be released from aluminium hydroxide. Protein recoveries do not increase significantly even when increasing the final PB concentration from $50 \mathrm{mM}$ to $100 \mathrm{mM}$. The curves have two plateaus, which may indicate that proteins have different adsorption conformations on the aluminium hydroxide.

The structure of released protein was measured by FTIR spectroscopy in two ways, either using the complex of protein and aluminium hydroxide or using only the released protein without adjuvant after centrifugation. Figure 7 shows the inverted 2nd derivative spectra of released BSA in the amide I and the amide II regions. For comparison, the adsorbed BSA and free BSA are also shown in the same figure. In the amide I range, released BSA loses random structure at $1646 \mathrm{~cm}^{-1}$ and regains $\alpha$-helix 
structure around $1654 \mathrm{~cm}^{-1}$. In the amide II range, band at $1546 \mathrm{~cm}^{-1}$ shifts from $1549 \mathrm{~cm}^{-1}$ comparing to adsorbed BSA, and a band is lost at $1533 \mathrm{~cm}^{-1}$. The spectrum of released BSA is similar to the spectrum of free BSA. This may indicate that released BSA again regains the native structure. This is in agreement with the study of Engel et al. [45]. They showed that released bovine $\alpha$-lactalbumin (BLA) from polystyrene nanospheres had native spectroscopic properties. The structure of adsorbed BLA refolded to its native-like state upon release from aluminium hydroxide. There is a small spectral difference between released BSA when measured in complex of the released protein and aluminium and when measured on the released protein alone. This can be explained by the former sample having $20 \%$ adsorbed BSA, which cannot be released.

The refolding procedure was studied by investigating the release using different final PB concentrations, from $5 \mathrm{mM}$ to $200 \mathrm{mM}$. The spectra were recorded on the complex sample of protein and aluminium hydroxide. For low PB concentrations, the sample has more adsorbed protein, whereas, there is more released protein in samples containing high PB concentrations. Figure 8 presents the inverted 2nd derivative spectra of released BSA. It is seen that in amide I range, band at $1646 \mathrm{~cm}^{-1}$ is diminished, and the band at $1653 \mathrm{~cm}^{-1}$ becomes stronger with increasing PB concentration. Random structure is lost and the amount of $\alpha$-helix increases. In amide II region, bands at $1569,1549,1533$ and $1514 \mathrm{~cm}^{-1}$ lose

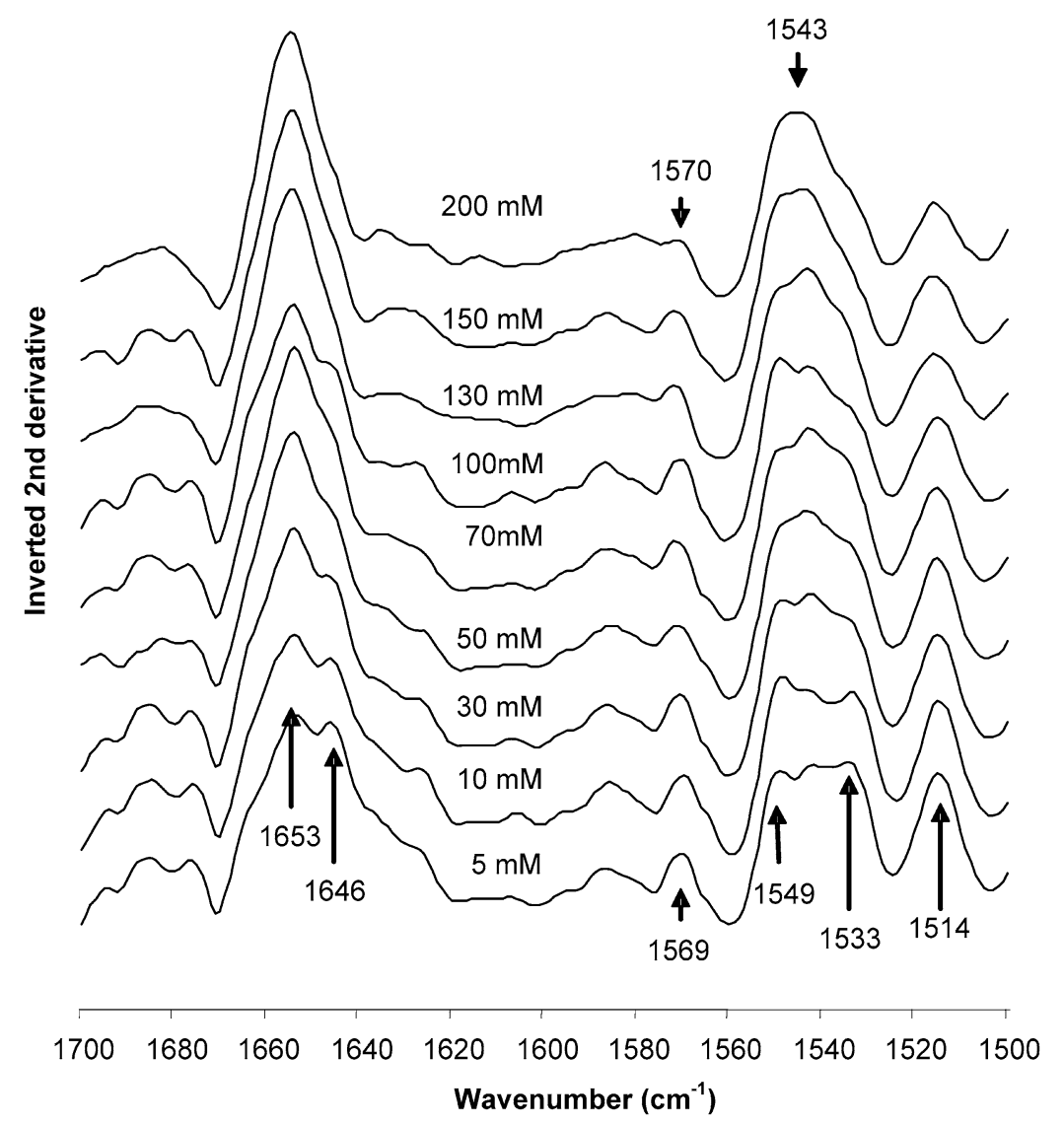

Fig. 8. Inverted 2nd derivative spectra of released BSA in amide I and amide II region: adsorbed protein has been released using pH 7.4 PB at different concentrations (from $5 \mathrm{mM}$ to $200 \mathrm{mM}$ ) for $40 \mathrm{~min}$ respectively. The spectra are recorded on the complex of protein and aluminium hydroxide. The spectra have been shifted vertically for case of interpretation. 


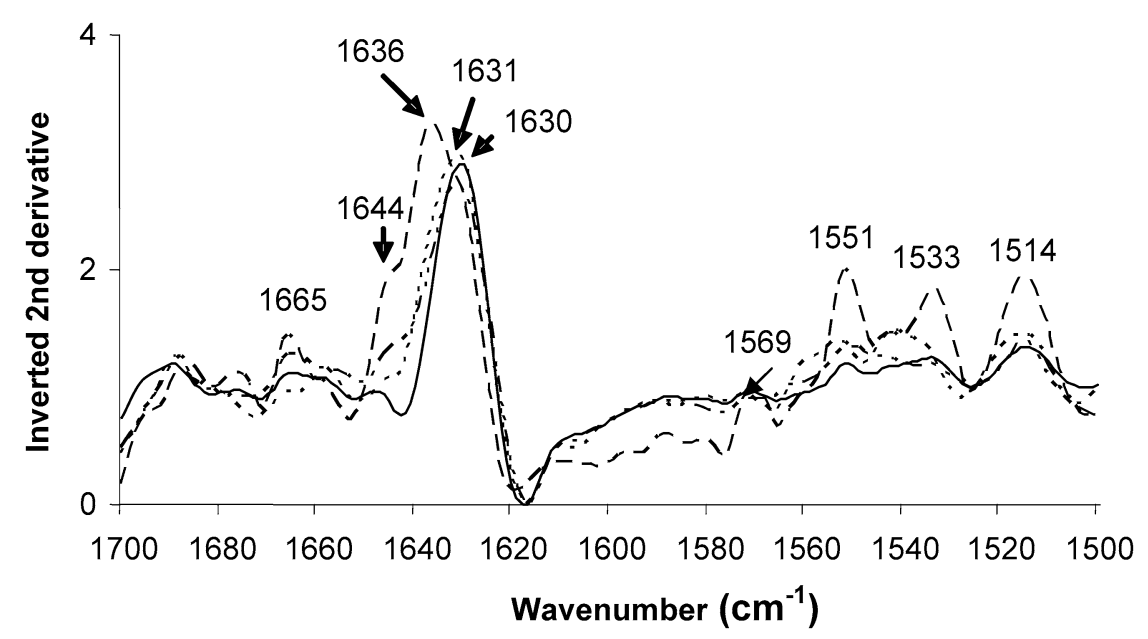

Fig. 9. Inverted 2nd derivative spectra of BLG in amide I and amide II region: free BLG (solid line), adsorbed BLG (dashed line), released BLG, the complex of protein and aluminium hydroxide (dotted line), and released BLG, protein alone after centrifugation (dash-dotted line).

intensity, and the band at $1543 \mathrm{~cm}^{-1}$ increase in intensity. These structural alterations make the spectrum more native-like following the increase of PB concentration.

The inverted 2nd derivative FTIR spectra of free BLG, adsorbed BLG, and released BLG are given in Fig. 9. In the amide I region, $\beta$-sheet band shifts from $1636 \mathrm{~cm}^{-1}$ to $1631 \mathrm{~cm}^{-1}$ for released BLG as compared to adsorbed BLG, and thus the spectrum of released BLG more closely resembles that of free BLG. In the amide II range, bands at $1569,1551,1533$ and $1514 \mathrm{~cm}^{-1}$ for released BLG are similar to free BLG. This indicates that released BLG regain its native-like structure. Figure 10 shows the inverted 2nd derivative spectra of BLG which are released using different PB concentrations, from $5 \mathrm{mM}$ to $200 \mathrm{mM}$. The spectra were also measured on the complex of protein and aluminium hydroxide. It is seen that $\beta$-sheet band at $1636 \mathrm{~cm}^{-1}$ shifts to $1631 \mathrm{~cm}^{-1}$, and band at $1541 \mathrm{~cm}^{-1}$ becomes stronger. A few bands $1665,1644,1569,1551,1533$ and $1514 \mathrm{~cm}^{-1}$ decrease intensity as a function of PB concentration. These changes make the spectrum become more native-like since there is more released protein in the sample.

The structural information from the CD spectra is in agreement with the FTIR results. The CD spectra of released BSA and free BSA as well as released BLG and free BLG are given in Fig. 11. The almost identical spectra illustrate that released BSA has similar structure with free protein. The released BLG and free BLG show similar spectra except lower ellipticity between 194-206 nm. This may indicate that released BLG cannot totally refold to its native state. In addition, CD experiments confirm the results obtained by FTIR. To compare the CD spectra of denatured and native BSA and BLG, free proteins were also measured at different temperatures; see Fig. 11(C) and (D). The significant difference of the CD spectra between high and low temperature indicates that proteins are in their native state before measurements.

\section{Conclusion}

FTIR-ATR spectroscopy provides direct information on the secondary structural changes of the model antigens when first adsorbed to aluminium hydroxide and following release. It is shown that the sec- 


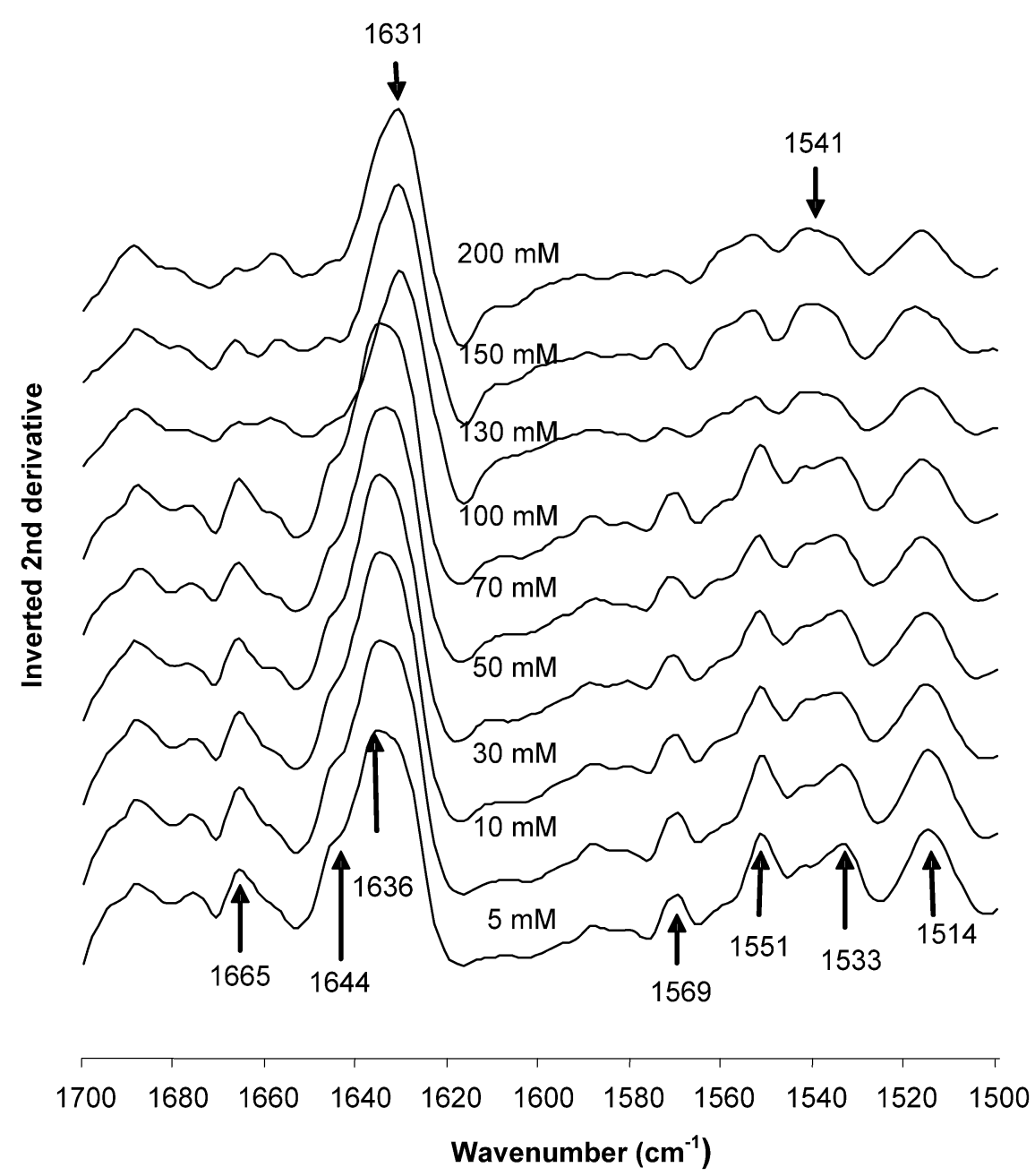

Fig. 10. Inverted 2nd derivative spectra of released BLG in amide I and amide II region: adsorbed protein has been released using pH 7.4 PB at different concentrations (from $5 \mathrm{mM}$ to $200 \mathrm{mM}$ ) for $40 \mathrm{~min}$ respectively. The spectra are recorded on the complex of protein and aluminium hydroxide. The spectra have been shifted vertically for case of interpretation.

ondary structures of BSA and BLG changes when adsorbed by aluminium hydroxide. The adsorptioninduced structural changes are dependent on how much protein is adsorbed onto aluminium hydroxide. Maximal adsorption gives a more native-like structure than low protein adsorption.

PB replaces pre-adsorbed antigen from aluminium hydroxide. The recovery of released antigen is approximate $80 \%$ after $40 \mathrm{~min}$ in the presence of PB. FTIR-ATR and CD experiments show that the released antigens generally refold to their native state. Overall, the method has been shown to be relevant in development of new vaccines.

\section{Acknowledgement}

We gratefully acknowledge the financial support from the Ministry of Science, Technology and Innovation under its Industrial $\mathrm{PhD}$ initiative and from ALK-Abelló A/S. 

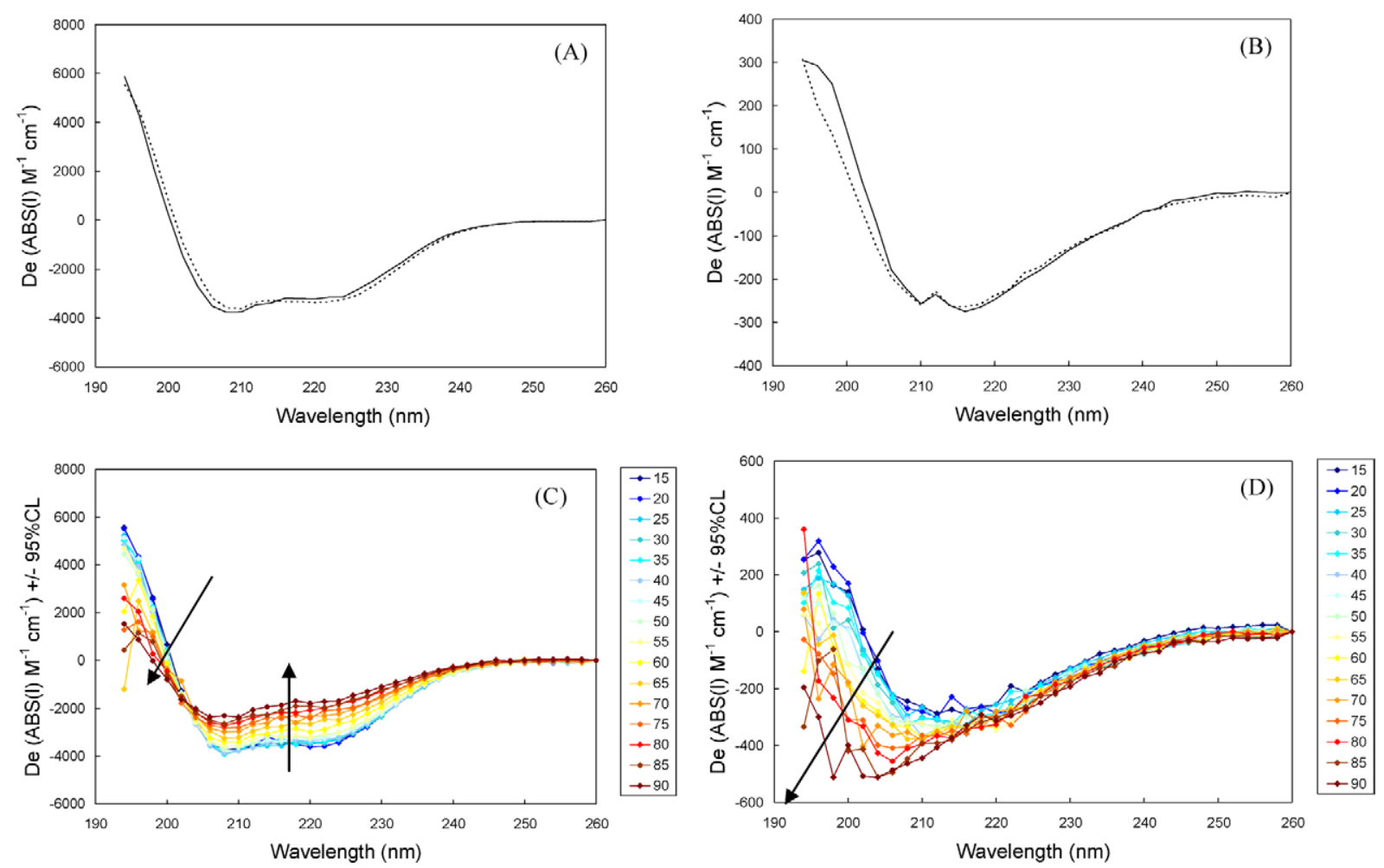

Fig. 11. CD spectra BSA (A, C) and BLG (B, D): free protein (solid line) and released protein (dotted line); C and D show CD spectra of BSA and BLG at different temperatures respectively. The arrows indicate the direction of increasing temperature.

\section{References}

[1] R.A. Goldsby, T. Kindt and B.A. Osborne, Immunology, 4th edn, W.H. Freeman and Company, New York, 2001, pp. 63-65.

[2] C. Schoneich, M.J. Hageman and R.T. Borchardt, Stability of peptides and proteins, in: Controlled Drug Delivery, Challenges and strategies, K. Park, ed., American Chemical Society, Washington, DC, 1997, pp. 205-228.

[3] M.C. Manning, K. Patel and R.T. Borchardt, Stability of protein pharmaceuticals, Pharm. Res. 6 (1989), $903-918$.

[4] K. Fu, K. Greibenow, L. Hsieh, A.M. Klibanov and R. Langer, Use of FTIR spectroscopy to characterize the secondary structure of proteins encapsulated with PLGA microspheres, J. Con. Rel. 58 (1999), 357-366.

[5] T.H. Yang, A. Dong, J. Meyer, O.L. Johnson, J. Cleland and J.F. Carpenter, Use of infrared spectroscopy to assess secondary structure of human growth hormone within biodegradable microspheres, J. Pharm. Sci. 88 (1999), 161-165.

[6] C. Castelain and C. Genot, Conformational changes of bovine serum albumin upon its adsorption in dodecane-in-water emulsions as revealed by front-face steady-state fluorescence, Biochim. Biophys. Acta 1199 (1994), 59-64.

[7] D. Kowalczyk, S. Slomkowski and F.W. Wang, Changes in conformation of human serum albumin and gamma globulins upon adsorption to polystyrene and poly latexes: Studies by fluorescence spectroscopy, J. Bioact. Compat. Polym. 9(1994), 282-309.

[8] M.C.L. Maste, W. Norde and A.J.W.G. Visser, Adsorption-induced conformational changes in the serine proteinase sannase: A tryptophan fluorescence and circular dichroism study, J. Colloid Interface Sci. 196 (1997), 224-230.

[9] S.L. Hem and J.L. White, Characterization of aluminium hydroxide for use as an adjuvant in parenteral vaccines, J. Parent. Sci. Techn. 38 (1984), 2-10.

[10] L.S. Jones, L.J. Peek, J. Power, A. Marham, B. Yazzie and C.R. Middaugh, Effects of adsorption to aluminium salt adjuvants on the structure and stability of model protein antigens, J. Biol. Chem. 280 (2005), 13406-13414.

[11] A. Dong, L.S. Jones, B.A. Kerwin, S. Krishnan and J.F. Carpenter, Secondary structures of proteins adsorbed onto aluminium hydroxide adjuvant: infrared spectroscopic analysis of proteins from low solution concentrations, Anal. Biochem. 351 (2006), 282-289.

[12] A. Barth and C. Zscherp, What vibrations tell us about proteins, Q. Rev. Biophys. 35 (2002), 369-430. 
[13] P.I. Haris, Theory and basic principles - 3. Fourier transform infrared spectroscopic studies of peptides: potentials and pitfalls, ACS Symp. Ser. 750 (2000), 54-95.

[14] J.S. Sharp, J.A. Forrest and R.A.L. Jones, Surface denaturation and amyloid fibril formation of insulin at model lipid-water interface, Biochemistry 41 (2002), 15810-15819.

[15] C.E. Giacomelli, M.G.E.G. Bremer and W. Norde, ATR-FTIR study of IgG adsorbed on different silica surface, J. Colloid Interface Sci. 220 (1999), 13-23.

[16] Y.I. Tarasevich and L.I. Monakhova, Interaction between globular proteins and silica surfaces, Colloid J. 64 (2002), $482-$ 487.

[17] P.M. Bummer, An FTIR study of the structure of human serum albumin adsorbed to polysulfone, Int. J. Pharm. 132 (1996), 143-151.

[18] K.K. Chittur, FTIR/ATR for protein adsorption to biomaterial surfaces, Biomaterials 19 (1998), 357-369.

[19] P.I. Haris and F. Seveercan, FTIR spectroscopic characterization of protein structure in aqueous and non-aqueous media, J. Mol. Catal. B: Enzym. 7 (1999), 207-221.

[20] H.H. Mantsch, A. Perczel, M. Hollosi and G.D. Fasman, Characterization of beta-turns in cyclic hexapeptides in solution by Fourier-transform IR spectroscopy, Biopolymers 33 (1993), 201-207.

[21] L.K. Tamm and S.A. Tatulian, Infrared spectroscopy of proteins and peptides in lipids bilayers, Q. Rev. Biophys. 30 (1997), $365-429$.

[22] J.O. Speare and T.S. Rush, IR spectra of cytochrome $C$ denatured with deuterated guanidine hydrochloride show increase in $\beta$ sheet, Biopolymers 72 (2003), 193-204.

[23] D.J. Lacey, N. Wellner, F. Beaudoin, J.A. Napier and P.R. Shewry, Secondary structure of oleosins in oil bodies isolated from seeds of safflower (Carthamus tinctorius L.) and sunflower (Helianthus annuus L.), Biochem. J. 334 (1998), 469-477.

[24] S. Krimm and J. Bandekar, Vibrational spectroscopy and conformation of peptides, polypeptides, and proteins, Adv. Protein Chem. 38 (1986), 181-364.

[25] R. Itri, W. Caetano, L.R.S. Barbosa and M.S. Baptista, Effect of urea on bovine serum albumin in aqueous and reverse micelle environments investigated by small angle X-ray scattering, fluorescence and circular dichroism, Braz. J. Phys. 34 (2004), 58-63.

[26] N. Kossovsky, A. Nguyen, K. Sukiassians, A. Festekjian, A. Gelman and E. Sponesler, Secondary structure of albumin acquired rapidly by modified conventional ATR-FTIR is comparable to CD spectral data, J. Colloid Interface Sci. 166 (1994), 350-355.

[27] J. Liu, J.L. Feldkamp, J.L. White and S.L. Hem, Adsorption of phosphate by aluminium hydroxycarbonate, J. Pharm. Sci. 10 (1984), 1355-1358

[28] P. Robert, M.F. Devaux, N. Mouhous and E. Dufour, Monitoring the secondary structure of proteins by near infrared spectroscopy, Appl. Spectrosc. 53 (1999), 226-232.

[29] N.S. Servagent, M. Revault, H. Quiquampoix and M.H. Baron, Conformational changes of bovine serum albumin induced by adsorption on different clay surfaces: FTIR analysis, J. Colloid Interface Sci. 221 (2000), 272-283.

[30] L. Sawyer, G. Kontopidis and S.Y. Wu, $\beta$-Lactoglobulin - A three-dimensional perspective, Int. J. Food Sci. Technol. 34 (1999), 409-418.

[31] T. Lefevre and M. Subirade, Interaction of $\beta$-lactoglobulin with phospholipids bilayers: a molecular level elucidation as revealed by infrared spectroscopy, Int. J. Biol. Macromol. 28 (2000), 59-67.

[32] T.J. Lenk, Infrared studies of protein adsorption and transitions on polyurethanes, $\mathrm{PhD}$ dissertation, University of Washington Chemical Engineering, 1994.

[33] C. Schladitz, E.P. Vieira, H. Hermel and H. Mohrwald, Amyloid- $\beta$-sheet formation at the air-water interface, Biophysics 77 (1999), 3305-3310.

[34] B.S. Kendrick, J.L. Cleland, X. Lam, T. Nguyen, T.W. Randolph, M.C. Manning and J.F. Carpenter, Aggregation of recombinant human interferon gamma: kinetics and structural transitions, J. Pharm. Sci. 87 (1998), 1069-1076.

[35] A. Dong, S.J. Prestrelski, S.D. Allison and J.F. Carpenter, Infrared spectroscopy studies of lyophilization- and temperatureinduced protein aggregation, J. Pharm. Sci. 84 (1995), 415-424.

[36] T. Lefevre and M. Subirade, Conformational rearrangement of $\beta$-lactoglobulin upon interaction with an anionic membrane, Biochim. Biophys. Acta 1549 (2001), 37-50.

[37] H. Urano and S. Fukuzaki, Conformation of adsorbed bovine serum albumin governing its desorption behavior at aluminawater interfaces, J. Biosci. Bioeng. 90 (2000), 105-111.

[38] S. Hajra and D.K. Chattoraj, Protein adsorption at solid-liquid interfaces: part II - adsorption from binary protein mixture, Indian J. Biochem. Biophys. 2 (1991), 124-132.

[39] J. Xie, C. Riley, M. Kumar and K. Chittur, FTIR/ATR study of protein adsorption and brushite transformation to hydroxyappatite, Biomaterials 23 (2002), 3609-3616.

[40] W. Norde, Behavior of proteins at interfaces, with special attention to the role of the structure stability of the protein molecule, Clin. Mater. 11 (1992), 85-90. 
[41] K.A. Oberg and A.L. Fink, A new attenuated total reflectance Fourier transform infrared spectroscopy method for the study of proteins in solution, Anal. Biochem. 256 (1988), 92-106.

[42] M. van de Weet, W.E. Hennink and W. Jiskoot, Protein instability in poly(lactic-co-glycolic acid) microparticles, Pharm. Res. 17 (2000), 1159-1167.

[43] J.L. Cleland, M.F. Powell and S.J. Shire, The development of stable protein formulations: a close look at protein aggregation, deamidation, and oxidation, Crit. Rev. Ther. Drug 10 (1993), 307-377.

[44] J.V. Rinella, R.F. Workman, J.L. White and S.L. Hem, Elutability of proteins from aluminium-containing vaccine adjuvants by treatment with surfactants, J. Colloid Interface Sci. 197 (1998), 48-56.

[45] M.F.M. Engel, A.J.W.G. Visser and C.P.M. Mierlo, Refolding of adsorbed bovine $\alpha$-lactalbumin during surfactant induced displacement from a hydrophobic interface, Langmuir 7 (2003), 2929-2937. 


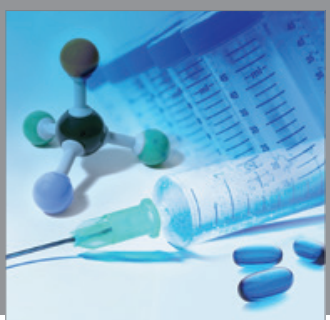

International Journal of

Medicinal Chemistry

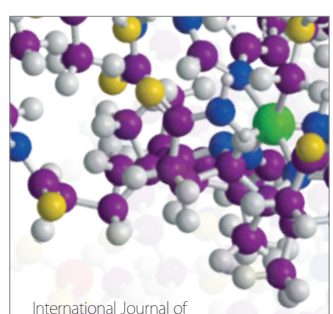

Carbohydrate Chemistry

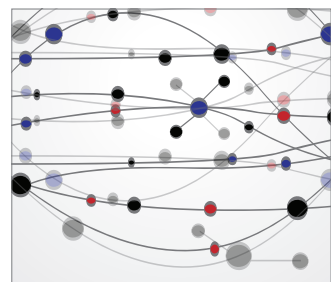

The Scientific World Journal
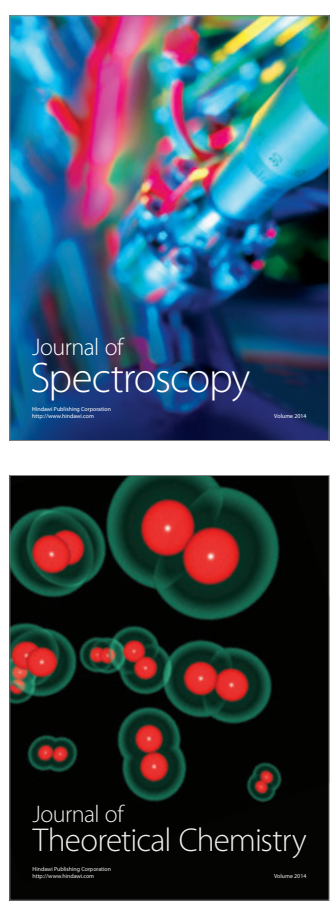
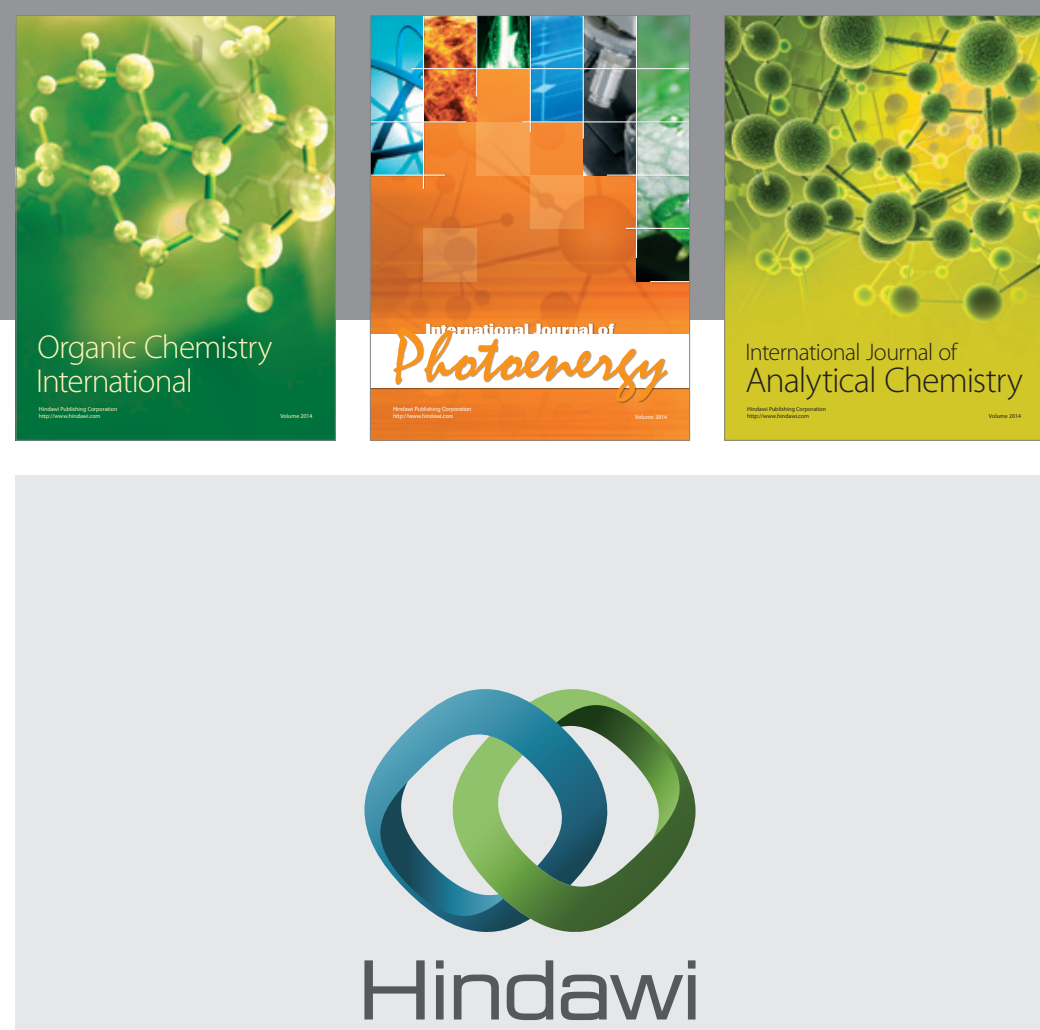

Submit your manuscripts at

http://www.hindawi.com
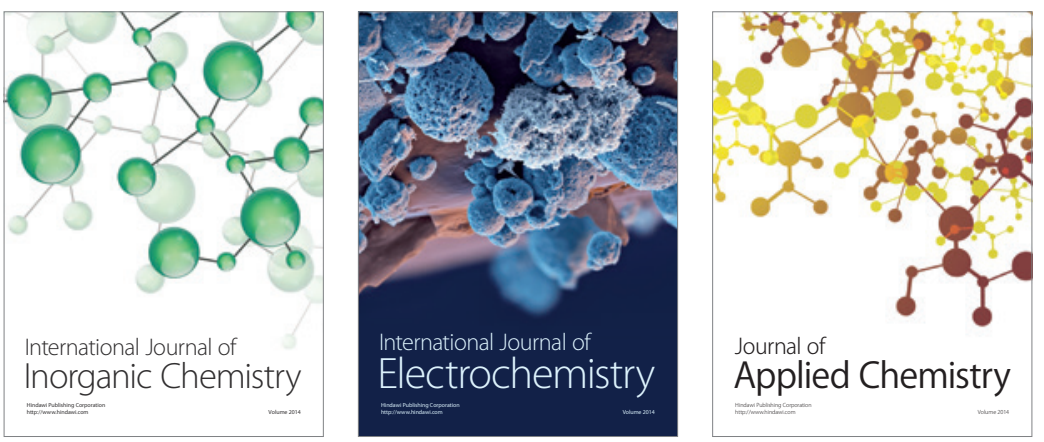

Journal of

Applied Chemistry
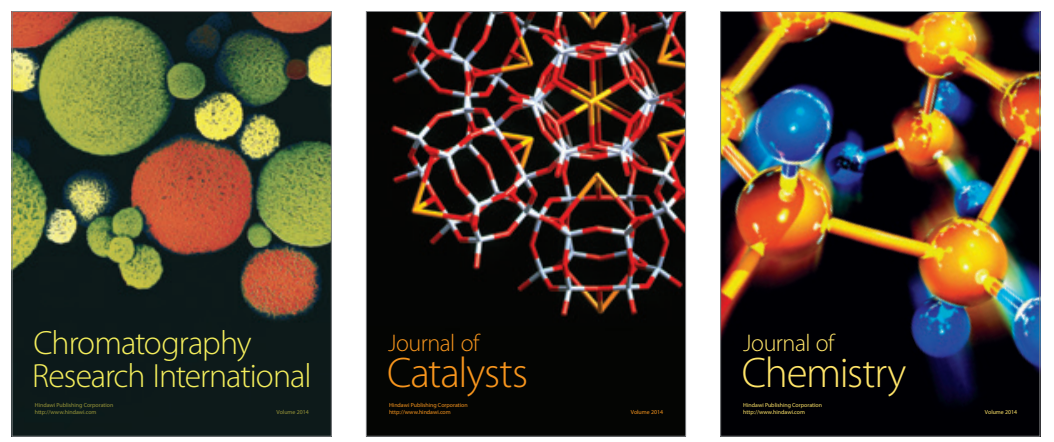
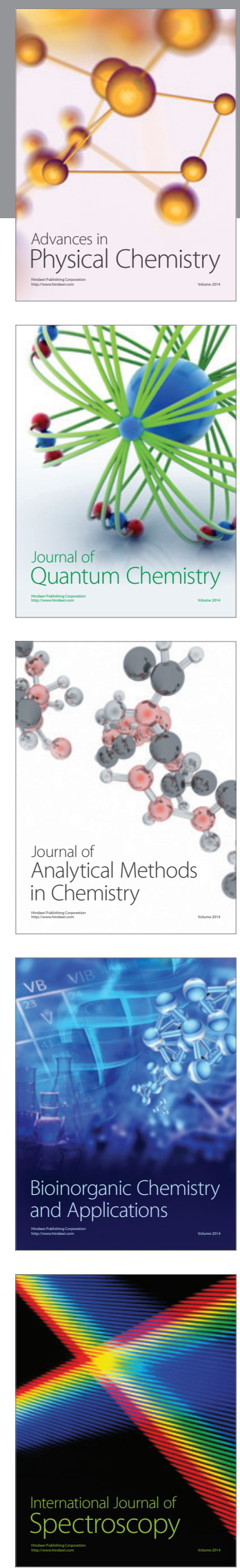